Tjalling C. Koopmans Research Institute

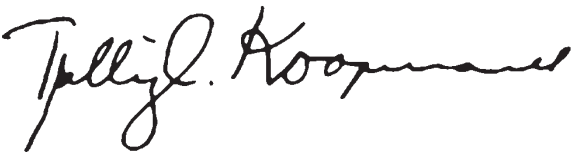

Discussion Paper Series nr: 08-05

\title{
Managerial perceptions of works councils' effectiveness in the Netherlands
}

Annette van den Berg Yolanda Grift

Arjen van Witteloostuijn 


\section{Tjalling C. Koopmans Research Institute Utrecht School of Economics \\ Utrecht University}

Janskerkhof 12

3512 BL Utrecht

The Netherlands

telephone $\quad+31302539800$

fax $\quad+31302537373$

website www.koopmansinstitute.uu.nl

The Tjalling C. Koopmans Institute is the research institute and research school of Utrecht School of Economics.

It was founded in 2003, and named after Professor Tjalling C. Koopmans, Dutch-born Nobel Prize laureate in economics of 1975.

In the discussion papers series the Koopmans Institute publishes results of ongoing research for early dissemination of research results, and to enhance discussion with colleagues.

Please send any comments and suggestions on the Koopmans institute, or this series to M.vanDort@econ.uu.nl

ontwerp voorblad: WRIK Utrecht

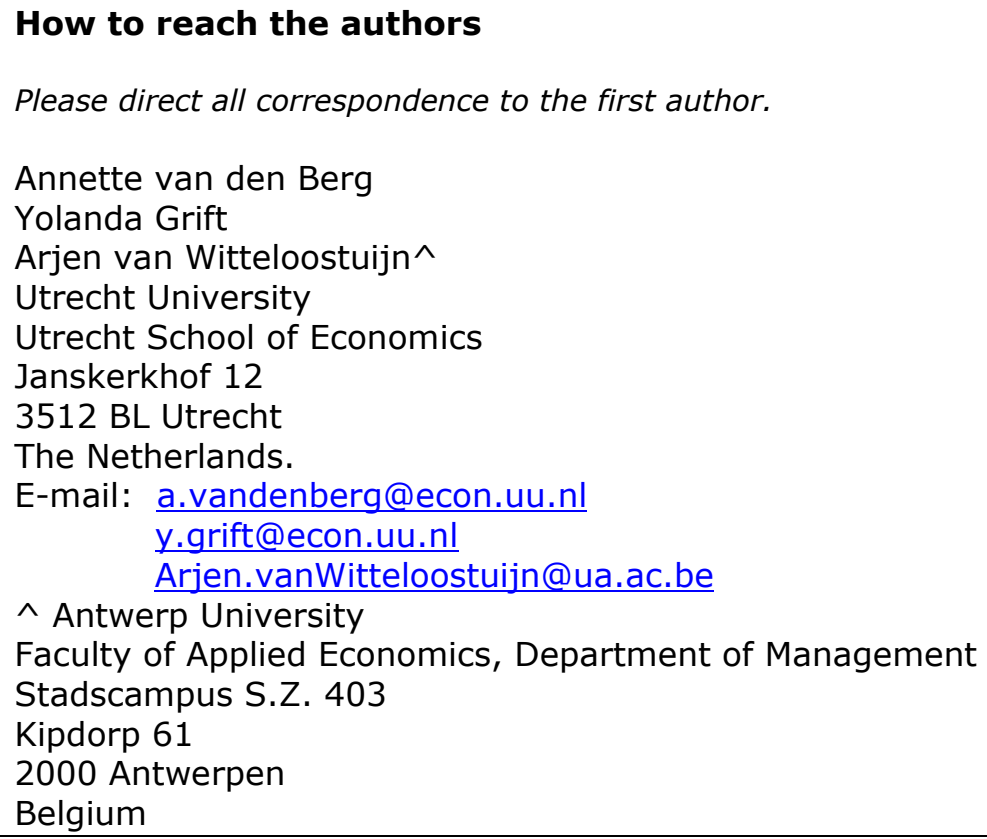

Please direct all correspondence to the first author.

Annette van den Berg

Yolanda Grift

Arjen van Witteloostuijn^^

Utrecht University

Utrecht School of Economics

Janskerkhof 12

3512 BL Utrecht

The Netherlands.

E-mail: a.vandenberg@econ.uu.nl

y.grift@econ.uu.nl

Arjen.vanWitteloostuijn@ua.ac.be

$\wedge$ Antwerp University

Faculty of Applied Economics, Department of Management

Stadscampus S.Z. 403

Kipdorp 61

2000 Antwerpen

Belgium 
Utrecht School of Economics

Tjalling C. Koopmans Research Institute

Discussion Paper Series 08-05

\title{
Managerial perceptions of works councils' effectiveness in the Netherlands
}

\author{
Annette van den Berga \\ Yolanda Grift ${ }^{a}$ \\ Arjen van Witteloostuijn ${ }^{\text {ab }}$
}

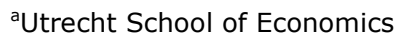

Utrecht University

${ }^{\mathrm{b}}$ Faculty of Applied Economics Antwerp University

March 2008

\begin{abstract}
Although works councils have, by and large, equally extensive legal rights in Germany and the Netherlands, this is the first econometric analysis that investigates the influence of works councils on firm performance for the Netherlands. We use a nation-wide Dutch dataset with information on management's perceptions of the works council's impact on their firms' efficiency and innovation. Following Jirjahn and Smith (2006), we find that managerial perceptions crucially depend on the firm's human resource management policies and market strategies. Additionally, we argue that managerial perceptions are related to the works council's role attitude and management's leadership style. For this argument, we find support, too.
\end{abstract}

Keywords: works councils, managerial response, effectiveness, efficiency, innovation

JEL classification: J53, M54

\section{Acknowledgements}

The authors would like to thank Robbert van het Kaar and Jan Kees Looise for providing the data 


\section{Introduction}

In both Germany and the Netherlands, labour relations at the firm level are characterized by a very strong form of mandatory worker codetermination (Looise and Drucker, 2003; Top and Cremers, 2003). Even though the legal rights of Dutch works councils are, by and large, equally extensive as those of their counterparts in Germany, extant research almost exclusively focuses on German works councils. One of the reasons for this probably has to do with data availability. Since the mid-1980s, a considerable number of quantitative studies have empirically estimated the effects of codetermination on company performance in Germany. These German studies show that the presence of works councils can have a significant influence on matters such as productivity, profitability, innovation and labour turnover (see overview articles by Addison et al., 2004; and Jirjahn, 2006). Jirjahn and Smith (2006) report that, in practice, the impact of works councils on firm performance depends very much on the attitudes of both works council and management team toward employee participation. They distinguish managers with a positive and a negative view on cooperation with their personnel, both in firms with and without a works council. They show that specific conditions in the German manufacturing industry, such as work force characteristics, firm strategies, the industrial relations system and HRM practices, determine whether the relationship between managers and employees or works council can be characterized as cooperative or uncooperative.

In contrast, not a single quantitative analysis has been performed in the Netherlands, to date, because Dutch empirical data were simply unavailable. A comparison of the German and the Dutch setting (CPB, 1997; Top and Cremers, 2003) makes clear that, although both systems of codetermination are very similar because they are rooted in the same tradition, there are some noticeable differences, both at the enterprise and the workfloor level. At the enterprise level, depending on the firm's size and sector of origin, German workers are legally entitled to occupy between one-third and fifty per cent of all seats in the supervisory boards of limited liability companies (CPB, 1997). These seats are allocated to three different groups of workers' representatives: the majority is given to employees of the company, with outside union officials coming second and members of the works councils of subsidiaries third. The remaining seats (at least 50 per cent) are assigned to shareholders' representatives. In the Netherlands, employees have a much lower percentage of delegates on the supervisory board, and these non-executives are assumed to take the interests of all stakeholders into account, and not just those of the workers ${ }^{1)}$. Moreover, Dutch trade unions do not play a 
formal role at all. At the workfloor level, German works councils have a much more formal relationship with management than their Dutch equivalents. This is reflected in the large percentage (16 per cent), which is close to zero in the Netherlands, of cases in which German labour representatives have gone to court (Top and Cremers, 2003). Rather, works councils in the Netherlands are embedded in a culture of consultation, so typical of the Dutch corporatist 'Poldermodel'.

Recently, a large nationally representative dataset was made available with all sorts of information about the way in which Dutch works councils operate, viewed from the perspective of both employee representatives and management (van het Kaar and Looise, 1999; Looise and Drucker, 2003). Using this database, the current paper reports the first econometric analyses on the perceived effectiveness of works councils in Dutch establishments, offering a threefold contribution to the literature. First, we replicate Jirjahn and Smith's (2006) study to infer whether the determinants of management's attitude toward employee participation in the Netherlands are the same as in Germany. In comparison to Jirjahn and Smith's German data, our Dutch sample is associated with one disadvantage and several advantages. Unlike Jirjahn and Smith, we do not have any information about firms without a works council. However, contrary to their sample, which only covers the manufacturing industry, our dataset includes all branches of the private sector. Second, we are able to distinguish between management's perception of the works council's impact on both efficiency and innovation. And third, our data offer the opportunity to test two extra hypotheses, specifically with respect to the influence of the works council's role attitude and management's leadership style.

Our paper is structured as follows. In Section 2, we briefly introduce the Dutch codetermination system. The theoretical background will be elaborated in Section 3, in which we briefly set out how a works council is expected to affect firm performance. In this Section 3 , we will also formulate the hypotheses with respect to the determinants of management's attitude toward the impact of codetermination on the firm's efficiency and innovation. Apart from translating Jirjahn and Smith's (2006) argument to the Dutch context, we will explore additional arguments as to likely impact of the works council's role attitude and management's leadership style. Next, the data are described in Section 4, after which we test all hypotheses in Section 5. In the concluding Section 6, we summarize and interpret our main findings. 


\section{Works councils in the Netherlands}

Codetermination in the Netherlands is mandatory in all sectors of the economy. Among the most important legal privileges of Dutch works councils are the right to be informed, the right to give advice, and the right to provide consent. What should be stressed is the dualistic nature of the legal task of the works council, which is typical for the Netherlands and Germany, and which them different from most of their counterparts in Europe and elsewhere in the world. On the one hand, the works council must stand up for the interests of all personnel. On the other, the works council is legally obliged to operate in the interest of the firm at large. This implies, for instance, that the Dutch works council does not have the right to go on strike.

The works council has the right to be sufficiently informed on all relevant matters so as to perform its tasks optimally. This includes all information necessary to be able to oversee management's compliance with the law, with the collective labour agreement and with other regulations concerning safety, health and well-being. Moreover, the law entitles the works council to be consulted on all important, well-defined managerial decisions. This includes decisions about large investments and loans, and expansion or reduction of business activities. Management is obliged to ask for the council's advice in time, so that the works council can influence the decision process. Finally, and most importantly, the works council has the right of consent (codetermination) with respect to all social arrangements within the organizations, insofar the matter in question has not already been regulated in a collective agreement between employers and trade unions. Codetermination involves not only working hours, holidays, health and safety, and payment systems, but also job evaluation schemes, rules on hiring, firing and promotion, and vocational education and training facilities.

In order to use all these rights effectively, the position of the members of the works council is legally protected. Moreover, they are allowed - within certain limits - to meet during working hours, to follow training courses and to consult outside experts, all at the expense of the employer. Finally, if the workers' representatives find that management does not satisfactorily follow up their advice or has taken a decision without consulting them, they have the right to go to court. Works councils hardly ever have the right to determine wages and fringe benefits. The unions have legally been given precedence over negotiating the terms of employment in collective labour agreements. As soon as wages and fringe benefits are settled in a collective labour agreement, which applies to the vast majority of the Dutch workforce, a works council is not allowed to renegotiate the deal at the organization level. 
Reversely, the direct influence of Dutch trade unions on company policies is small. Contrary to Germany, where works councils are dominated by trade unions (CPB, 1997), a formalized relationship between councils and unions is absent in the Netherlands. Unions may try to have their own members elected in the works council, but nationwide over one third of all council members is not affiliated with a union (de Vries and Schins-Derksen, 2000). All trade unions actively support the functioning of works councils through their members.

There may be a large difference between the seemingly extensive powers of the Dutch works councils derived from the law, and the actual influence that they have on the operation of the firm. Many policy documents elaborate on the obstacles that employee participation encounters in practice (e.g., Cremers et al., 2007; van Ees et al., 2007). For example, although The Works Council Act determines that all Dutch organizations with fifty or more employees formally must install a works council, only about three quarters of those actually do so, mainly the large establishments. Frequently, both employees and managers are to blame. The former often lack the motivation to become a council member, and the latter often oppose the thought of having to consult with subordinates because that would undermine their authority and would be time consuming (and hence costly). Moreover, even if a works council is installed, it often does not perform all that well (Engelen and Kemper, 2006), facing a variety of obstacles (van Witteloostuijn, 2002). In practice, only a minority of all works councils uses their rights to the fullest (Everaers, 2006; Cremers et al., 2007). Usually, individual employers only allow works councils to participate in decision-making with respect to personnel policy, and to a much lesser extent with respect to strategic issues (van het Kaar and Looise, 1999). Trade unions and employers' associations are more positive toward stimulating cooperation between management and works councils at the centralized level than at the firm level (van het Kaar, 2003).

\section{Theoretical expectations}

In theory, it could be argued that works councils have the potential to exert great influence on company policies, if they exploit their legal rights optimally. Freeman and Lazear (1995) contend that each of the works councils' rights can be to the benefit of the entire organisation, leading to an increase of the 'joint surplus'. Firstly, exchange of information can ensure that parties trust each other more, which in turn may improve efficiency. Secondly, advisory rights may allow workers to come up with suggestions and solutions to problems that have an excess value. And thirdly, codetermination rights give the employees more control over their 
own working conditions and work security, which prompts them to take a longer-run view of the prospects of the firm. In addition, van den Berg (2004) argues, in a variation of the principal-agent theory, that not only the manager can be regarded as a principal who needs to supervise the actions of his subordinates (agents), but that the works council too could be regarded as a principal vis-à-vis management when it comes to monitoring the compliance with collective labour contracts and with the law. The firm at large also benefits from this extra check, because opportunistic managers may engage in rent-seeking behaviour, and their non-observance of (explicit as well as implicit) agreements can be noticed by the works council. This could lead to negative reputation effects for the firm, making it harder in the future to hire qualified personnel (cf. Williamson, 1985).

There could also be a drawback of works councils' presence. Freeman and Lazear (1995) argue that the organisation runs the risk that a powerful workforce will only try to enlarge the pie in favour of themselves, claiming wage rises and preservation of jobs in an irresponsible manner that may lead to lower profits. The danger of rent-seeking activities by the works council is their main theoretical argument against participation rights. In practice, the risk of rent-seeking behaviour by Dutch works councils is very much curtailed by the law, which gives the prerogative of wage negotiations to the trade unions. Another negative impact of works councils on firm performance could be their lack of know-how and a delaying effect on decision-making processes. Moreover, the operation of a works council involves costs in the form of lost working hours due to meetings and schooling of the members, and expenses related to the hiring of outside professionals and going to court (Kaufman and Levine, 2000).

Influenced by Freeman and Medoff (1984), Bryson et al. (2006) point at the importance of managerial responses to any form of worker voice. They claim that the performance of the firm greatly depends on the degree in which management is inclined to give (representatives of) employees a say in company policies. Hence, the next question then becomes in what circumstances managers can be expected to take a more positive or a more negative view toward (the effects of) employee participation. Jirjahn and Smith (2006) operationalise this in their survey by asking whether management is of the opinion that an increase in employee involvement in decision-making will lead to more motivated personnel in the long run. Due to the particular questions in our survey, we employ a slightly different measurement of management attitude toward employee participation. In our questionnaire, managers are asked whether they think that works councils have a substantial positive or negative effect on several indicators of firm performance such as efficiency, innovation and 
careful decision-making. If the answer is affirmative, we can interpret this as a positive view of managers toward participation of workers in different company matters.

To explain which factors determine whether or not managers are in favour of codetermination, Jirjahn and Smith (2006) come up with a series of arguments, subdivided into six categories. For reasons of replication, we will adhere to this same categorization: the structure of the workforce, principal-agent owner-manager arrangements, the industrial relations system, human resource management practices, market strategy and innovation, and general establishment characteristics. Due to the fact Jirjahn and Smith also aim to explain which factors determine whether or not a works council is present at all, some of their hypotheses are more difficult to apply to the explanation of management's attitude in our study. However, owing to the composition of our particular data, we can add a few novel hypotheses.

\section{Structure of the Workforce}

A basic premise is that the willingness of managers to collaborate with employees or their representatives in company policies depends on the composition of the firm's labour force. Jirjahn and Smith (2006) argue that management is more likely to advance a cooperative relationship with its personnel when the workforce (mainly) consists of highly qualified employees with tenure, because these people are usually more committed to the firm in the

long run. Consequently, it is assumed that if an establishment employs a high percentage of blue-collar workers and workers with a part-time or temporary contract ${ }^{2)}$, this increases the probability that managers will have a less favourable view toward employee participation. Conversely, a high proportion of highly educated workers will increase the likelihood that managers think positively about employee participation. This notion is supported by Delaney and Huselid (1996), who argue that firms aim to hire the best qualified workers and try to improve the quality of their current personnel, because they believe that skilled employees can contribute to the firm's success.

\section{Principal-Agent Owner-Manager Arrangements}

Jirjahn (2003) explains how managerial incentive schemes can influence management's motivation whether or not to build a trustful bond with employees. Owners of the firm try to combat opportunistic behaviour of the Executive Board by means of profit sharing and active 
monitoring. These manifestations of shareholder activism may have opposite effects on managers' intention to stimulate a cooperative relationship with workers. On the one hand, the introduction of profit sharing and active monitoring may lead managers to be less cooperative with the employees because they become highly committed to the owners' goals, and the benefits from that weigh up against the costs of breaching implicit contracts with their subordinates. On the other hand, profit sharing and active monitoring may induce rentseeking managers to more cooperation with employees in order to enhance firm performance, because this cooperation is directly in their own financial gain. In addition to these conflicting hypotheses related to profit sharing and active monitoring, as formulated by Jirjahn and Smith (2006), we likewise assume that either a quotation on the stock exchange or the presence of a Supervisory Board can have one of the two described opposing effects on the managers' willingness to grant influence to workers. Since most firms quoted on the stock exchange provide their managers with options and shares, this variable serves as a proxy for profit sharing. In the same manner, the Supervisory Board monitors the executives, which may be an alternative proxy for active monitoring.

\section{Industrial Relations System}

There are different ways in which employers can interact with employees. Consulting with the works council is just one possibility, but a manager may also decide to introduce other forms of worker participation instead of, or in addition to, works council involvement. Moreover, in Germany and the Netherlands workers are usually represented by a trade union to bargain over their terms of employment, which as a rule is not a task of German or Dutch works councils. Council members do have the task to see to it that within firms, managers carry out all aspects of the collective labour agreement, if applicable. Against the background of the particular industrial relations system, two kinds of hypotheses are formulated. To begin with, it may be that alongside the presence of a works council, workers have been given direct involvement individually or at the team level. If (groups of) workers are given more say in company decisions, this may either indicate that managers prefer this kind of participation to the influence of a formal works council (hence, we expect a negative attitude toward the council) or it may indicate that managers are positive about all kinds of participation, including the works council. ${ }^{3)}$ Second, Jirjahn and Smith (2006) argue that a collective labour contract implies trade union influence. Since they assume close ties between unions and councils, a collective agreement increases the chance of works council presence. 
Based on other work (e.g., Hübler and Jirjahn, 2003), we expect that a collective agreement also contributes to a constructive view of management toward works councils. In a reaction to the claim of Freeman and Lazear (1995) that an influential council will seize a too large part of the pie at the expense of shareholders, it can be argued that a collective labour agreement between employer and trade union eliminates a possible source of distributional conflict between employer and works council. Instead, councils are able to concentrate on other firm-related issues that may improve the work situation and the work climate, and thus enhance firm performance.

\section{Human Resource Management Practices}

High-performance work practices are used to intrinsically motivate workers with the ultimate aim that this will prompt them to a better achievement to the benefit of the firm (Delaney and Huselid, 1996; Addison, 2005). Successful human resource management (HRM) implies a good relationship between the employer, on the one hand, and employees and their representatives, on the other hand. Jirjahn and Smith (2006) therefore formulate the expectation that the introduction of typical HRM tools is associated with a positive view of managers toward works councils, because the latter may be needed to communicate the justification of the HRM arrangements toward the personnel. Distinctive HRM-induced measures include the introduction of different sorts of incentive pay, promotion opportunities and internal training facilities. In as far as employees may be suspicious of the good intentions of their boss, the presence of a works council may reassure them. In addition, careful personnel policies are especially important in periods of downsizing: employment reductions must be made acceptable, which this can be done via the works council (Freeman and Lazear, 1995; Cascio and Wynn, 2004). Hence, if management intends to reduce personnel, they should have a positive attitude toward cooperation with the works council. In the same line of reasoning, it is assumed that if the firm has not dismissed any employees for a considerable amount of time, this is a sign of a long-lasting cooperative relationship between management and works council, reflecting a positive attitude of the former as well.

\section{Market Strategy and Innovation}

Nickell (1999) argues that the more intense the pressure is from competitors, the higher the need for management and workers alike is to increase effort. From this, Jirjahn and Smith 
(2006) infer that more competition in the product market leads to more cooperation between managers and employees. Hence, a positive managerial view toward works councils is expected. Moreover, Jirjahn and Smith (2006) formulate a few hypotheses that relate to the type of technology used in the production process. Their expectation is that if management can obtain (and transmit) valuable information through the works council, this will stimulate innovations, which in turn would require a positive managerial attitude toward employee participation. It may be important to distinguish between the effects of process innovation and product innovation. Addison et al. (2001) argue that councils are likely to oppose the former type of innovation because this may lead to lay-offs, while they would support the latter type of innovation because this may be beneficial for workers. As a final remark, Jirjahn and Smith (2006) suggest that management only requires the support of the (formal) works council in complex organisations; otherwise, innovations will occur more through direct and informal cooperation with employees.

\section{General Establishment Characteristics}

In all German studies, the number of employees of a firm is included as a control variable to explain the presence of a works council (e.g., Addison et al., 2001; Jirjahn, 2006). Contrary to the Netherlands, in Germany the rights of a works council amplify with firm size. Moreover, in larger firms the number of council members increases. As it is expected that workers usually have more need of representation in larger, more bureaucratic or complex organisations, works councils are likely to emerge more often in large establishments. Since our sample only contains organisations with a works council, this causality with firm size is not relevant. However, we could hypothesize that management attitude toward codetermination becomes more positive, the larger the establishment. In these circumstances, the complexity of the organisation starts to play a role, and the limits to the span of control of management may render a good relationship with works councils necessary. A second general characteristic often encountered in German research is firm age. Addison et al. (1997) reason that older plants and their managers are more accustomed to worker participation (and may therefore hold a more positive view). Jirjahn and Smith (2006) expect firm age to exhibit a positive correlation with council presence, because older firms are more likely to have experienced a conflict with their personnel before, which in turn would have stimulated the foundation of a works council. By analogy, younger and growing firms are less likely to show works council presence. Parallel to this, we formulate the expectation that in younger 
firms in which the newest production technology is used, management is more likely to take a negative view on works councils' effectiveness.

\section{Management's Leadership Style and Works Council's Attitude}

Given the theory that managerial responsiveness to worker participation has a great impact on firm performance (Freeman and Medoff, 1984; Bryson et al., 2006), we want add two additional hypotheses. Firstly, we assume that the management's leadership style reflects its

opinion about consulting employees and involving them in decision-making. Consequently, we expect that the more the executives run the organisation in a formal and authoritative manner, the more likely it is that they perceive a negative effect from codetermination. Secondly, we expect that the attitude and activeness of the works council affects the managerial viewpoint of codetermination. We hypothesise that the more a works council adopts a proactive attitude toward involvement, the more this can benefit the whole organisation, which in turn influences management's view on the council's effectiveness positively.

We conclude this theoretical argument by briefly addressing the difference between management's perceptions of the works council's impact on efficiency, on the one hand, and innovation, on the other hand. We refer to this as 'perceived efficiency effect' and 'perceived innovation effect', respectively. It is conceivable that the expected impact of certain determinants plays a different role in explaining one or the other perceived effect. Characteristics reflecting cost control and profit maximisation, such as profit sharing and labour flexibility, may be more important, casu quo: stronger negatively related, in the context of the perceived efficiency effect. Likewise, characteristics reflecting creativity and a pro-worker environment, such as the degree of schooling of the workforce and training facilities, may be more important, casu quo: stronger positively related, in the context of the perceived innovation effect.

\section{Data and research method}

In 1998, a large survey was conducted economy-wide among Dutch organisations that operated with a works council. A long list of questions was sent to both management teams (board of directors) and works councils of 3,500 companies, government agencies and other 
organisations. The response that remained after screening the data was about 450 cases for the directors and about 230 cases for the works councils. The research was conducted by van het Kaar and Looise (1999) to establish to what degree Dutch works councils had gained influence in the preceding decade. They conclude that works councils have developed into a mature organisation, accepted by management as a taken-for-granted consultative body. On the other hand, they also establish that the council's influence on company policies (other than strictly personnel matters) remains modest. To date, the data were not econometrically analysed, but only used to construct tables with descriptive count and frequency statistics.

For the estimates in this paper, we use the directors' survey only, as our focus is on explaining the determinants of managerial perceptions. The analysis is confined to firms in the private sector. ${ }^{4)}$ The dataset consists of the 143 firms for which all relevant information is available. Due to the design of the survey, almost all measures reflect perceptual data from individual respondents. A potential problem using this dataset therefore can be commonmethod variance. To test for this, we apply Harman's single-factor test (see Podsakoff et al., 2003). The assumption underlying this test is that if the data feature a substantial amount of common-method variance, a factor analysis on all dependent and independent variables will either reveal a single factor or one general factor that accounts for the majority of the (co)variance in the data. A factor analysis on the perceived efficiency effect and its explanatory variables revealed four factors with an Eigenvalue greater than one, and no single factor explaining most of the variance (i.e., the first factor explained $33 \%$, and cumulatively the four factors explained $76 \%$ ). Applying a factor analysis to the perceived innovation effect reveals the same pattern: four factors with an Eigenvalue larger than one, and no factor explaining all variance. Therefore, we conclude that common-method variance is not a major concern.

\section{[INSERT TABLE 1 ABOUT HERE]}

In Table 1, the descriptives are presented. The question about the managerial perception of works councils' effects on both efficiency and innovation has three possible answer categories: yes, neutral or 'on the contrary'. Of the managers, $8 \%$ reported a positive effect, $78 \%$ had a neutral view and $15 \%$ indicated a negative effect of works councils on efficiency. With respect to innovation, $10 \%$ reported a positive view, $78 \%$ were neutral and $11 \%$ revealed a negative perception. Based on this distribution over the categories, we decided to perform ordered probit analyses. The workforce consists, on average, of $24 \%$ blue-collar workers, $49 \%$ white-collar employees, $18 \%$ university graduates and $10 \%$ managerial staff. 
Moreover, $87 \%$ of the employees have a fixed contract and $7 \%$ a temporary contract, whilst $6 \%$ are workers from a temping agency. Only $21 \%$ of higher personnel receive some form of profit sharing. They have either an agreement on profit sharing with their employer or they own stocks, bonds, debentures or a combination of these financial assets. In $40 \%$ of the firms, the influence of the shareholders has increased. Almost $36 \%$ of the firms has a quotation on a stock exchange (Amsterdam or abroad). Three quarters of the firms have a mandatory supervisory board.

On average in $49 \%$ of the firms workers operate in 'quality panels' (i.e., teams of employees that are involved in improving production processes), and in $62 \%$ of the firms individual workers have a say in company policies. In almost $70 \%$ of the firms, collective bargaining takes place at a centralised level: either by following the collective agreement of a particular industry or by participating actively in a collective agreement for this sector. About $45 \%$ of the firms report a reorganisation in 1996-1997, of which $40 \%$ with lay-offs. In addition, no less than 93\% indicate that labour flexibility (temporary contracts and workers from temping agencies) increases in their company. In line with the distinction Jirjahn and Smith (2006) have made, we included three measures of HRM: flexible pay, internal promotions and training facilities. On a three-point scale (hardly any, some or much attention), the flexible pay scores, on average, 1.6 , the internal promotions 2.2 , and training facilities 2.7. A total of 12 measures of HRM were distinguished, running from informing personnel via job evaluation conversation to team building. A factor analysis produced two factors with an Eigenvalue greater than one, with the first factor explaining $70 \%$ of the variance. This dominant factor's sum score runs from 18 to 34, with an average of 27, indicating that most firms pay some attention to different HRM practices.

Two variables have been constructed to deal with the type of market a firm operates in. On a four-point scale (decreased - increased) managers were asked to indicate the change in competition the firm had been confronted with in the last three years. On average, they report that competition has increased. Asked about past and future international alliances, mergers and acquisitions, $42 \%$ of the firms report working on internationalisation. On a fourpoint scale, the product and process innovation were evaluated as to market requirements and internal performance criteria. The criteria 'improving the quality of products' (on average, 2) and 'developing new commodities' (on average, 2.6) come closest to the ones Jirjahn and Smith (2006) use. Based on a factor analysis, two other characteristics for the type of innovation are constructed. The first factor, process innovation, combines the criteria 'efficiency' and 'flexibility in the firm' with the market requirements 'to produce for the 
lowest price' and 'to provide a large choice' (an average of 8.5 on a 6-12 scale). The second factor, product innovation, combines the criteria 'to improve the quality of products' and 'to develop new commodities' with the market requirements of 'producing the highest quality' and 'a unique product' (an average of 8.8 on a 6-12 scale). In addition, managers reported whether the production technology has been bought or developed within the firm.

With respect to management leadership style, $20 \%$ of the managers reported that their leadership style could be characterised as formal and following rules, as opposed to a more cooperative style. Of the works councils, $44 \%$ are judged to adopt a proactive attitude towards company policies, whereas $26 \%$ are said to mainly monitor the company policies. For the remaining 30\%, communication is indicated as the most important characteristic of the relationship of the relationship between works councils and management.

The advantage of ordered probit analysis is that we can make a clear distinction between a positive and negative attitude of managers to works councils' effect on efficiency and innovation. The drawback of applying a limited dependent variable analysis is that the estimated coefficients cannot be interpreted straightforwardly. We need to calculate the marginal effects. However, due to the partly explorative nature of our analyses, in which we are mainly interested in the direction and significance of the effects, and less in their size, we present the estimated coefficients instead of the marginal effects. ${ }^{5}$

\section{Empirical results}

In Table 2, the outcomes of the regression analyses are shown. Taken as a whole, we can improve upon the results of the replication of the Jirjahn and Smith model (column 1 and 4) by adding and adjusting some particular variables (columns 2 and 5), and even more so by additionally including the three variables that measure how management and councils approach each other (columns 3 and 6). This supports our argument that the way in which management teams and work councils interact must also be taken into account in order to determine which factors influence managerial perceptions of works council's effectiveness.

\section{[INSERT TABLE 2 ABOUT HERE]}

Starting with general establishment characteristics, we note that firm size in the Netherlands does not play a noteworthy role, as we already expected. Only in one column we find a significant U-shaped relationship between the number of employees and the perceived 
innovation effect. ${ }^{6)}$ With respect to the variable that proxies firm age, we can infer that in younger firms in which the newest production technology is used, management is indeed more likely to be pessimistic about works councils' effectiveness, at least as regards to efficiency. This might also be attributed to the fact that in a setting that requires quick technological adaptations, management may consider obligatory consults with the works council as an obstacle.

The four variables reflecting the structure of the workforce show partly insignificant coefficients, but also partly confirm the hypotheses. The higher the numbers of blue-collar workers is, the less positive the perceived efficiency effect. Likewise, the perceived innovation effect is positive in combination with a high proportion of university graduates, and negative in combination with a high proportion of temporary workers.

With regard to principal-agent manager-owner arrangements we find mixed results. Contrary to our expectations, profit sharing for higher personnel does not produce any significant effects. ${ }^{7)}$ A proxy for profit sharing is a quotation on the stock exchange, and this variable does not produce a significant negative sign either. Active ownership has a significantly positive effect on managerial perception of works council's effectiveness as regards efficiency, which supports the notion that shareholder activism incites rent-seeking managers to cooperate with the works council because that is in their best interest. The presence of a supervisory board comes up with a significant negative sign with respect to the perceived innovation effect, however, which supports the notion that highly committed managers mainly aim to serve the interests of their principals, and therefore are less inclined to collaborate with the works council. Active ownership has an opposite effect compared to a supervisory board on the perceived efficiency and innovation effect. Supervision by financially involved stakeholders positively influences the perceived efficiency effect, whereas monitoring by an independent supervisory board relates negatively to the perceived innovation effect.

The findings for the variables reflecting the industrial relations system produce several significant coefficients, especially as regards to the perceived efficiency effect. As predicted, a collective labour agreement has a positive effect on managerial attitudes towards the council. Giving a say in company affairs to quality panels leads to a positive view on the contribution of works councils, too, but giving more influence to individual employees coincides with a negative perception of the effectiveness of the councils. Although both explanations were plausible from the start, we did assume that management would be either pro or contra all other forms of worker participation. The negative attitude towards works 
councils in combination with an increased influence of individual workers may be interpreted as follows. If the contribution of a council is appreciated, then individual employees do not need to get a say in the company's policies. However, if according to management the council does not function properly, they might stimulate the input of individual workers, as a substitute for the works council.

The variables linked to HRM practices give mixed results. Whereas Jirjahn and Smith (2006) found both significantly negative and positive correlations with respect to downsizing for German manufacturing, depending on the industrial relations regime (with or without works council presence), our outcome suggests that in a period of reorganisations Dutch managers find it irrelevant to consult the works council. In addition, our variable measuring an increase in flexible personnel does not come up with significant coefficients either. We predicted that it would be in the interest of managers to cooperate closely with the works council if they take measures to the detriment of the workforce, but it seems to work the other way around. Finally, we do establish one positive relationship between typical HRM tools and managerial perceived effectiveness of works councils on innovation, but none on efficiency. As expected, typical HRM tools such as incentive pay and internal training facilities have opposite effects. The former has a negative effect, whereas the latter reveals a positive effect. Overall, careful personnel policies increase the managerial perceived effect of works councils on innovation, but not so on efficiency. Careful personnel policies stimulate and motivate the workers in innovative firms. Managers that aim at efficiency may not introduce HRM measures, and they might not need works councils to communicate them.

For market strategy and innovation, several noteworthy significant results show up. The hypothesis that management' plans to increase market share (by entering into some form of joint venture with foreign firms) lead to a more positive attitude of managers as regards the council's contribution to efficiency, is confirmed. Internalisation requires the support of the workforce. At the same time, if management experiences increasing competitive pressures the perceived efficiency effect turns significantly negative, which suggests that in those circumstances Dutch managers do not appreciate the council's input. The introduction of completely new products is negatively related to the perceived efficiency effect, but positively associated with the perceived innovation effect. The negative effect could be attributed to the necessary but not always efficient use of both capital and labour to which the works councils might oppose. The positive effect corroborates the hypothesis that management should strive for a good understanding with the workforce through the council, to transmit and obtain valuable information, and support for initiating innovation. Introducing 
two factor variables to measure a possible difference between the attitudes towards product vis-à-vis process innovation leads to the observation that only the firm's strive for product innovation increases the perceived innovation effect significantly. Neither process nor product innovation has an impact on the perceived efficiency effect, which could indicate that innovation initiatives do not play a role in the managerial perception of the council's effectiveness in this respect. Alternatively, it could be that in most cases the organisation is simply not complex enough, so that managers do not need the works council to streamline communication with the workforce.

Finally, and most interestingly, we find the strongest effects if we add three variables that represent interaction between management teams and works councils. Our assumption that a very formal leadership style contributes negatively to the managerial opinion of the council's effectiveness is convincingly confirmed. And if we look at the effect of the type and stance of a works council, we may deduce that a pro-active council is not appreciated at all by executives, nor is a council that only monitors whether management fulfils its duties and implements decisions correctly. Apparently, in the perception of managers a works council is most effective when it only takes a passive stance.

\section{Conclusion}

In this paper, management's perception of the works council's impact on efficiency and innovation has been analysed. This is the first econometric study using Dutch data. Starting with a replication of Jirjahn and Smith's analyses (2006), we added to and adjusted some of their constructs. Lastly, we elaborated on the perceived impact of works councils on firm performance by including information on both the attitude of the councils and the leadership style of management. In 1998, a large survey was conducted economy-wide among Dutch organisations that operated with a works council. The resulting dataset contains information of the management team (board of directors) about the way they perceive that works councils operate and attribute to firm performance. The analyses are confined to firms in the private sector only.

Taken as a whole, the results of the replication of the Jirjahn and Smith model can be improved by adding and adjusting particular variables. It turns out that the perceived effect on efficiency is mainly influenced by the workforce by function, financially involved stakeholders, industrial relations system elements such as quality panels and collective labour agreements, and the market strategy. The perceived effect on innovation is mainly influenced 
by the workforce, both by function and by type of contract, stakeholders that are more neutral with respect to financial issues, industrial relations system aspects such as participation of individual employees, human resources practices and market innovation. Finally, when we additionally add measures on how management teams and works councils approach each other, we can conclude that the overall fit improves even more. This supports our argument that the way in which management teams and works councils interact must also be taken into account in order to determine which factors influence managerial perceptions of works council's effectiveness.

Of course, this study is not without limitations. There are two limitations in particular that we think imply a need for further work in the future. In the first place, all information is from a single informant - a manager of the organisation. This does not only raise the issue of common-method variance, but also implies a one-sided view on works councils' effectiveness. However valuable this might be, we hope in future work to extend the analyses to works councils' perceptions, too. It might be interesting, for instance, to explore the effect of differences of opinion between an organisation's management team and works council. Regrettably, due to an insufficient number of overlapping observations, we were not able to do this with the current dataset. In the second place, this is a study of effect perceptions. In future work, we plan to focus on 'objective' measures of performance as the ultimate dependent variable. For both future research issues, additional data collection is needed. We strongly believe this will prove to be worth the effort. 


\section{Endnotes}

1. Until 2003, works councils could recommend the inauguration of only one so-called 'labour commissioner' into the supervisory board. From 2004 onward, they are entitled to nominate candidates for the supervisory board up to one third of all members, but in practice not many works councils have already used this extended nomination right.

2. We employ temporary personnel as a proxy for employees with an impermanent job, of which management is likely to believe that their participation would have a negative impact on firm results. Jirjahn and Smith (2006) use the similar variable 'apprentices' differently, namely as a determinant of the probability whether or not a cooperative works council is present.

3. The argument of Jirjahn and Smith (2006) is different. Since their sample also includes organizations without a works council, they claim that in such circumstances the occurrence of direct participation is a sign of a positive attitude of managers toward the involvement of individual employees in decision-making. If they observe direct participation in the presence of a works council, they attribute this to the need of personnel to be represented by a works council in order to prevent potential abuse of direct participation by management. This rather suggests a negative attitude of managers toward employee involvement, since the emphasis is put on their potential opportunistic behavior.

4. Items that deal with internationalisation or competition in the market are not relevant for nonprofit organisations. Applying the same analysis and leaving out the non-relevant characteristics shows hardly any effect on the perceived impact of the works council on efficiency and innovation. Therefore, this extension is not included.

5. The tables with the marginal effects are available upon request.

6. The turning point lies at 4.38 (200-500 employees), indicating that the perceived innovation effect will become weaker if firms start to grow, but will increase again if firms grow even larger.

7. We have tried several measures for this characteristic. The effect remains insignificant. This might be explained by the diverse nature of the financial assets. 


\section{References}

Addison, John T. 2005. "The Determinants of Firm Performance: Unions, Works Councils, and Employee Involvement/High-Performance Work Practices". Scottish Journal of Political Economy 52: 406-450.

Addison John T., Claus Schnabel and Joachim Wagner. 1997. "On the Determinants of Mandatory Works Councils in Germany". Industrial Relations 36: 419-445.

Addison John T., Claus Schnabel and Joachim Wagner. 2001. "Works Councils in Germany: Their Effects on Establishment Performance". Oxford Economic Papers 53: 659-694.

Addison John T., Claus Schnabel and Joachim Wagner. 2004. "The Course of Research into the Economic Consequences of German Works Councils". British Journal of Industrial Relations 40: 221-248.

Berg, Annette van den. 2004. "The Contribution of Work Representation to Solving the Governance Structure Problem." Journal of Management and Governance 8: 129-148.

Bryson, Alex, Andy Charlwood and John Forth. 2006. "Worker Voice, Managerial Response and Labour Productivity: An Empirical Investigation”. Industrial Relations Journal 37: 438-455.

Cascio, Wayne F. and Peg Wynn. 2004. "Managing a Downsizing Process". Human Resource Management 43: 425-436.

CPB Netherlands Bureau for Economic Policy Analysis. 1997. Challenging Neighbours: Rethinking German and Dutch Economic Institutions. Berlin-Heidelberg: Springer Verlag,

Cremers, Jan (ed.). 2007. Medezeggenschap in beeld (An Image of Codetermination). Den Haag: Reed Business bv.

Delaney, John T. and Mark A. Huselid. 1996. "The Impact of Human Resource Management Practices on Perceptions of Organizational Performance". Academy of Management Journal 39: 949-969.

Ees, Hans van, Rienk Goodijk and Arjen van Witteloostuijn. 2007. Verliest de medezeggenschap aansluiting? Onderzoek naar de medezeggenschapsstructuren in hedendaagse ondernemingen (Does Worker Participation Fall Behind? Research into Codetermination Structures in Contemporary Firms). Research report. The Hague: Ministry of Social Affairs.

Engelen, Mirjam and Riemer Kemper. 2006. Naleving van de Wet op de Ondernemingsraden: stand van zaken 2005 - Eindrapport (Final Report on the Compliance with the Works Council Act in 2005). Research report. Leiden: Research voor Beleid.

Everaers, Jan. 2006. "Hoezo volwassen? (In what Way Mature?)”. Zeggenschap 17: 20-23.

Freeman, Richard B. and Edward P. Lazear. 1995. “An Econometric Analysis of Works Councils.” In Works Councils: Consultation, Representation and Cooperation in Industrial Relations, edited by Joel Rogers and Wolfgang Streeck, pp. 27-52. Chicago: University of Chicago Press. 
Freeman, Richard B. and James L. Medoff. 1984. What Do Unions Do? New York: Basic Books.

Hübler, Olaf and Uwe Jirjahn. 2003. "Works Councils and Collective Bargaining in Germany: The Impact on Productivity and Wages". Scottish Journal of Political Economy 50: 1-21.

Jirjahn, Uwe. 2003. "Executive Incentives, Works Councils and Firm Performance". Journal of Applied Social Science Studies 123: 397-421.

Jirjahn, Uwe. 2006. “Ökonomische Wirkungen der Mitbestimmung in Deutschland: Überblick über den Stand der Forschung und Perspektiven für zukünftige Studien (Economic Effects of Codetermination in Germany: a Literature Overview and Perspectives for Future Research)." Sozialer Fortschritt. German Review of Social Policy 55: 215-226.

Jirjahn, Uwe and Stephen C. Smith. 2006. "What factors Lead Management to Support or Oppose Employee Participation-With and Without Works Councils? Hypotheses and Evidence from Germany". Industrial Relations 45: 650-680.

Kaar, Robbert H. van het. 2003. "Works Councils and other Work Place Employee Representation and Participation Structures". Thematic Feature in European Industrial Relations Observatory on-line (http://www.eurofound.europa.eu/eiro/2003/09/tfeature/nl0309102t.html).

Kaar, Robbert H. van het and Jan C. Looise. 1999. De volwassen OR: groei en grenzen van de Nederlandse ondernemingsraad: resultaten van het grote OR-onderzoek (The Mature Works Council: Findings of the large Study of Works Councils). Alphen aan den Rijn: Samsom.

Kaufman, Bruce E. and David I. Levine. 2000. “An Economic Analysis of Employee Representation.” In Nonunion Employee Representation-History, Contemporary Practice, and Policy, edited by B.E. Kaufman and D.G. Taras, pp. 149-175. Armonk, New York: M.E. Sharpe.

Looise, Jan C. and Michiel Drucker. 2003. "Dutch Works Councils in Times of Transition: The Effects of Changes in Society, Organizations and Work on the Position of Works Councils." Economic and Industrial Democracy 24: 379-409.

Podaskoff, Philip M., Scott B. MacKenzie, and Jeong-Yeon Lee. 2003. "Common Method Biases in Behavioral Research: A Critical Review of the Literature and Recommended Remedies." Journal of Applied Psychology 88: 879-903

Top, Martijn and Jan Cremers. 2003. OR-faciliteiten bij de buren (Works Council Facilities at the Neighbours). Den Haag: Reed Business Information.

Vries, Rob de and Eke Schins-Derksen. 2000. Onderzoek samenstelling ondernemingsraden: eindrapport (Final Report on the Composition of Works Councils). Research report. The Hague: Ministry of Social Affairs.

Williamson, Oliver E. 1985. The Economic Institutions of Capitalism. New York: The Free Press.

Witteloostuijn, Arjen van. 2002. "Het democratisch tekort in het bedrijfsleven: de macht en kracht van medezeggenschap (The Democratic Deficiency in Businesses: the Power of Codetermination).", Tijdschrift voor Arbeid en Participatie 24: 225-234. 
Table 1. Descriptives

\begin{tabular}{|c|}
\hline Variable \\
\hline $\begin{array}{l}\text { Perceived effect works council on efficiency } \\
\text { - negative } \\
\text { - neutral } \\
\text { - } \text { positive }\end{array}$ \\
\hline $\begin{array}{l}\text { Perceived effect works council on innovation } \\
\text { - negative } \\
\text { - neutral } \\
\text { nositive }\end{array}$ \\
\hline
\end{tabular}

\begin{tabular}{|r|r|r|r|r|} 
Freq & Mean & St. Dev. & Min & Max \\
& & & & \\
11 & 0.147 & & & \\
11 & 0.776 & & & \\
0.077 & & & \\
16 & 0.112 & & & \\
112 & 0.783 & & & \\
15 & 0.105 & & & \\
\hline
\end{tabular}

General establishment characteristics

Establishment size

Technology at the newest level

Industry dummies:

- manufacturing industries

- construction and housing industries

- transportation, trade, services, and hotel and catering industries

- banking and insurance industries

Structure of the workforce

Workforce by function:

- Proportion of blue-collar workers

- Proportion of white-collar workers

- Proportion of university graduates

- Proportion of managerial staff personnel

Workforce by type of contract:

- Proportion of workers with a fixed contract

- Proportion of workers with a temporary contract

- Proportion of workers from a temping agency

\begin{tabular}{|r|r|r|r|}
\hline 3.161 & 1.47 & 1 & 6 \\
\hline 24.444 & 33.83 & 1 & 36 \\
\hline .46 & & & \\
.12 & & & \\
.31 & & & \\
.11 & & & \\
\hline
\end{tabular}

Principal-agent arrangements (managers vis-à-vis owners)

Profit sharing for higher personnel

Active owners

Quotation on the stock exchange

Presence of supervisory board

Industrial relations system

Participation of quality panels

Participation of individual employees

Collective labour agreement

Human Resource Management (HRM) practices

Reorganization without forced lay-offs

Reorganization with forced lay-offs

Increasing labour flexibility

HRM

- flexible pay

- internal promotions

- training facilities

HRM practices combined (factor)

\begin{tabular}{|r|r|r|r|}
\hline & & & \\
\hline 23.916 & 24.87 & 0 & 90 \\
\hline 48.584 & 25.45 & 0 & 100 \\
\hline 17.881 & 16.82 & 0 & 95 \\
\hline 10.108 & 5.66 & 0 & 30 \\
\hline & & & \\
\hline 87.231 & 8.53 & 60 & 100 \\
\hline 6.776 & 5.64 & 0 & 30 \\
\hline 6.043 & 6.17 & 0 & 30 \\
\hline
\end{tabular}

Market strategy and innovation

\begin{tabular}{|l|r|r|r|r|r|r|}
\hline Development competition & & 3.078 & .77 & 1 & 4 \\
\hline Development internationalization & & .420 & .50 & 0 & 1 \\
\hline Introduction improved quality products & & 1.979 & .95 & 1 & 4 \\
\hline Introduction completely new products & & 2.580 & 1.21 & 1 & 4 \\
\hline Process innovation (factor) & & 8.514 & 1.30 & 6 & 12 \\
\hline Product innovation (factor) & & 8.814 & 1.44 & 6 & 12 \\
\hline Self-developed technology & & 2.014 & .64 & 1 & 3 \\
\hline Management leadership style and works council attitudes & & \multicolumn{5}{|l|}{} \\
\hline Formal leadership style & & .203 & .40 & 0 & 1 \\
\hline Proactive works council & & .441 & .50 & 0 & 1 \\
\hline Monitoring works council & & .259 & .44 & 0 & 1 \\
\hline Number of observations & 143 & & & & \\
\hline
\end{tabular}


Table 2. The results of ordered probit analyses explaining the Perceived effect of works council on Efficiency and Innovation

\begin{tabular}{|c|c|c|c|c|c|c|c|}
\hline & & \multicolumn{3}{|c|}{ Perceived effect works council on efficiency } & \multicolumn{3}{|c|}{ Perceived effect works council on innovation } \\
\hline & & $(1)$ & $(2)$ & $(3)$ & $(4)$ & $(5)$ & $(6)$ \\
\hline \multirow{9}{*}{$\begin{array}{l}\text { Structure of the } \\
\text { workforce }\end{array}$} & & & & & & & \\
\hline & $\%$ blue-collar workers & $-0.009^{*}$ & -0.008 & $-0.012 *$ & 0.000 & -0.000 & -0.001 \\
\hline & & $(1.67)$ & $(1.40)$ & $(1.84)$ & $(0.07)$ & $(0.01)$ & $(0.09)$ \\
\hline & $\%$ university graduates & -0.000 & 0.002 & 0.003 & $0.016^{*}$ & 0.014 & $0.025 * *$ \\
\hline & & $(0.02)$ & $(0.25)$ & $(0.33)$ & $(1.92)$ & $(1.52)$ & $(2.17)$ \\
\hline & \% workers with temporary contract & 0.017 & 0.030 & 0.034 & -0.021 & $-0.052 * *$ & $-0.068 * *$ \\
\hline & & $(0.69)$ & $(1.13)$ & $(1.23)$ & $(0.90)$ & $(1.99)$ & $(2.11)$ \\
\hline & $\%$ workers from temping agency & -0.006 & -0.016 & -0.030 & -0.016 & -0.009 & -0.031 \\
\hline & & $(0.26)$ & $(0.69)$ & $(1.19)$ & $(0.75)$ & $(0.41)$ & $(1.17)$ \\
\hline \multirow{9}{*}{$\begin{array}{l}\text { Principal-agent } \\
\text { arrangements } \\
\text { (managers vis-à- } \\
\text { vis owners) } \\
\end{array}$} & & & & & & & \\
\hline & Profit sharing for higher personnel & 0.180 & 0.120 & 0.219 & -0.020 & 0.044 & 0.161 \\
\hline & & $(0.57)$ & $(0.35)$ & $(0.61)$ & $(0.06)$ & $(0.12)$ & $(0.37)$ \\
\hline & Active owners & 0.333 & $0.542 *$ & $0.605^{*}$ & 0.269 & 0.009 & -0.124 \\
\hline & & $(1.25)$ & $(1.83)$ & $(1.88)$ & $(1.04)$ & $(0.03)$ & $(0.34)$ \\
\hline & Quotation on the stock exchange & & -0.276 & -0.198 & & -0.514 & -0.370 \\
\hline & & & $(0.82)$ & $(0.56)$ & & $(1.52)$ & $(0.96)$ \\
\hline & Presence of supervisory board & & -0.326 & -0.249 & & $-1.066 * * *$ & $-1.150 * * *$ \\
\hline & & & $(1.05)$ & $(0.77)$ & & $(3.01)$ & $(2.68)$ \\
\hline \multirow{7}{*}{$\begin{array}{l}\text { Industrial relations } \\
\text { system }\end{array}$} & & & & & & & \\
\hline & Participation quality panels & $0.553 * *$ & $0.789 * * *$ & $0.821 * *$ & -0.037 & 0.038 & 0.082 \\
\hline & & $(2.04)$ & $(2.60)$ & $(2.55)$ & $(0.14)$ & $(0.13)$ & $(0.24)$ \\
\hline & Participation individual employees & $-0.611 * *$ & $-0.708 * *$ & $-0.888 * * *$ & -0.368 & $-0.539 *$ & $-0.712 * *$ \\
\hline & & $(2.27)$ & $(2.45)$ & $(2.78)$ & $(1.43)$ & $(1.85)$ & $(2.07)$ \\
\hline & Collective labour agreement & $0.603 * *$ & $0.799 * *$ & $0.806^{* *}$ & $0.594 * *$ & 0.239 & 0.099 \\
\hline & & $(1.97)$ & $(2.43)$ & $(2.29)$ & $(1.98)$ & $(0.75)$ & $(0.26)$ \\
\hline \multicolumn{8}{|l|}{ HRM practices } \\
\hline & Reorganization without forced lay-offs & -0.105 & 0.005 & -0.172 & -0.175 & 0.049 & 0.276 \\
\hline & & $(0.35)$ & $(0.02)$ & $(0.47)$ & $(0.57)$ & $(0.14)$ & $(0.66)$ \\
\hline & Reorganization with forced lay-offs & 0.211 & 0.213 & 0.175 & -0.452 & -0.453 & -0.260 \\
\hline & & $(0.63)$ & $(0.58)$ & $(0.45)$ & $(1.33)$ & $(1.19)$ & $(0.56)$ \\
\hline & Increased labour flexibility & -0.649 & -0.945 & -0.883 & 0.472 & 0.343 & 0.715 \\
\hline & & $(1.21)$ & $(1.62)$ & $(1.44)$ & $(0.88)$ & $(0.61)$ & $(1.05)$ \\
\hline & Flexible pay & -0.257 & & & $-0.368 *$ & & \\
\hline & & $(1.29)$ & & & $(1.83)$ & & \\
\hline & Internal promotions & 0.130 & & & 0.236 & & \\
\hline & & $(0.64)$ & & & $(1.13)$ & & \\
\hline & Training facilities & 0.103 & & & $0.548 * *$ & & \\
\hline & & $(0.39)$ & & & $(2.04)$ & & \\
\hline
\end{tabular}


23

\begin{tabular}{|c|c|c|c|c|c|c|c|}
\hline & HRM practices combined & & -0.004 & -0.044 & & $0.093 * *$ & $0.107^{*}$ \\
\hline & & & $(0.10)$ & $(0.97)$ & & $(2.14)$ & $(1.95)$ \\
\hline \multirow{15}{*}{$\begin{array}{l}\text { Market strategy } \\
\text { and innovation }\end{array}$} & & & & & & & \\
\hline & Development competition & & $-0.518 * * *$ & $-0.543 * * *$ & & -0.042 & -0.128 \\
\hline & & & $(2.87)$ & $(2.82)$ & & $(0.24)$ & $(0.61)$ \\
\hline & Development internationalization & $0.594 * *$ & $0.703 * *$ & $0.760 * *$ & -0.042 & 0.098 & -0.065 \\
\hline & & $(2.17)$ & $(2.29)$ & $(2.35)$ & $(0.16)$ & $(0.33)$ & $(0.19)$ \\
\hline & Introduction improved quality products & 0.044 & & & 0.061 & & \\
\hline & & $(0.33)$ & & & $(0.46)$ & & \\
\hline & Introduction completely new products & $-0.194 *$ & & & $0.256^{* *}$ & & \\
\hline & & $(1.82)$ & & & $(2.36)$ & & \\
\hline & Process innovation & & 0.121 & 0.109 & & 0.028 & 0.020 \\
\hline & & & $(1.18)$ & $(1.00)$ & & $(0.27)$ & $(0.16)$ \\
\hline & Product innovation & & -0.122 & -0.116 & & $0.199 * *$ & $0.262 * *$ \\
\hline & & & $(1.35)$ & $(1.22)$ & & $(2.09)$ & $(2.21)$ \\
\hline & Self-developed technology & 0.069 & -0.153 & -0.127 & 0.115 & 0.096 & 0.154 \\
\hline & & $(0.33)$ & $(0.66)$ & $(0.51)$ & $(0.56)$ & $(0.42)$ & $(0.59)$ \\
\hline \multirow{7}{*}{$\begin{array}{l}\text { Management } \\
\text { leadership style } \\
\text { and works council } \\
\text { attitude }\end{array}$} & & & & & & & \\
\hline & Formal leadership style & & & $-1.045 * * *$ & & & $-1.258 * * *$ \\
\hline & & & & $(2.66)$ & & & $(2.78)$ \\
\hline & Proactive works council & & & $-0.715 * *$ & & & $-1.440 * * *$ \\
\hline & & & & $(2.17)$ & & & $(3.52)$ \\
\hline & Monitoring works council & & & -0.290 & & & $-1.880 * * *$ \\
\hline & & & & $(0.85)$ & & & $(4.01)$ \\
\hline \multirow{13}{*}{$\begin{array}{l}\text { General } \\
\text { establishment } \\
\text { characteristics } \\
\end{array}$} & & & & & & & \\
\hline & Establishment size & -0.303 & -0.409 & -0.210 & $-0.701 *$ & -0.098 & 0.307 \\
\hline & & $(0.72)$ & $(0.88)$ & $(0.42)$ & $(1.66)$ & $(0.21)$ & $(0.57)$ \\
\hline & Establishment size squared & 0.044 & 0.075 & 0.060 & 0.080 & 0.009 & -0.035 \\
\hline & & $(0.76)$ & $(1.17)$ & $(0.87)$ & $(1.38)$ & $(0.14)$ & $(0.47)$ \\
\hline & Technology at the newest level & -0.006 & $-0.007 *$ & $-0.008 *$ & -0.004 & -0.002 & -0.005 \\
\hline & & $(1.64)$ & $(1.73)$ & $(1.90)$ & $(1.03)$ & $(0.40)$ & $(0.93)$ \\
\hline & Industry dummies & yes & yes & yes & yes & yes & yes \\
\hline & & & & & & & \\
\hline & Observations & 143 & 131 & 131 & 143 & 131 & 131 \\
\hline & LR & 33.87 & 41.65 & 52.76 & 32.12 & 36.87 & 70.52 \\
\hline & Prob $>$ chi $^{2}$ & 0.111 & 0.027 & 0.005 & 0.155 & 0.077 & 0.000 \\
\hline & Pseudo $\mathrm{R}^{2}$ & 0.175 & 0.227 & 0.287 & 0.167 & 0.212 & 0.405 \\
\hline
\end{tabular}

Absolute value of $t$ statistics in parentheses; * significant at $10 \%$; * significant at $5 \%$; *** significant at $1 \%$.

Models (1) and (4): replication of the Jirjahn and Smith model (2006).

Models (2) and (5): adjusted and extended Jirjahn and Smith model (2006).

Models (3) and (6): adding leadership style and works council attitude. 